\title{
Recent Advances in the Control of Helminths of Domestic Animals by Helminthophagous Fungi
}

\author{
Jackson Victor Araújo ${ }^{1}$, Fabio Ribeiro Braga ${ }^{2}$, Pedro Mendoza-de-Gives ${ }^{3} \mathbb{1}$, Adolfo Paz-Silva ${ }^{4}(\mathbb{D}$ \\ and Vinícius Longo Ribeiro Vilela ${ }^{5, * \mathbb{B}}$
}

1 Departamento de Veterinária, Universidade Federal de Viçosa (UFV), Viçosa 36570-900, Brazil; jvictor@ufv.br

2 Laboratório de Parasitologia Experimental e Controle Biológico, Universidade Vila Velha (UVV), Vila Velha 29103-900, Brazil; fabio.braga@uvv.br

3 Area de Helmintología, Centro Nacional de Investigación Disciplinaria en Parasitología Veterinaria, Instituto Nacional de Investigaciones Forestales, Agrícolas y Pecuarias, Jiutepec 62556, Mexico; pedromdgives@yahoo.com

4 Departamento de Patología Animal, Facultad de Veterinaria, Universidad de Santiago de Compostela, ZC 27002 Lugo, Spain; adolfo.paz@usc.es

5 Departamento de Medicina Veterinária, Instituto Federal da Paraíba (IFPB), Sousa 58807-630, Brazil

* Correspondence: vinicius.vilela@ifpb.edu.br or vilelavlr@yahoo.com.br; Tel.: +55-83-999073634

check for

updates

Citation: Araújo, J.V.; Braga, F.R.; Mendoza-de-Gives, P.; Paz-Silva, A.; Vilela, V.L.R. Recent Advances in the Control of Helminths of Domestic Animals by Helminthophagous Fungi. Parasitologia 2021, 1, 168-176. https://doi.org/10.3390/ parasitologia1030018

Academic Editors: Theo De Waal and Geoff Hide

Received: 10 July 2021

Accepted: 5 September 2021

Published: 7 September 2021

Publisher's Note: MDPI stays neutral with regard to jurisdictional claims in published maps and institutional affiliations.

Copyright: (c) 2021 by the authors. Licensee MDPI, Basel, Switzerland. This article is an open access article distributed under the terms and conditions of the Creative Commons Attribution (CC BY) license (https:/ / creativecommons.org/licenses/by/ $4.0 /)$.
Abstract: This review describes the advances acquired and proven in the use of helminthophagous fungi in the control of gastrointestinal helminth parasites in domestic animals. Old and well-known premises about parasitic epidemiology and the factors that can interfere with the best performance of biological control are mentioned. Some of the most promising fungi are Duddingtonia flagrans from the predatory fungi group and Pochonia chamydosporia and Mucor circinelloides from the ovicidal fungi group. These fungi produce resistance spores called chlamidospores. Bioverm ${ }^{\circledR}$ and BioWorma ${ }^{\circledR}$, based on the fungus $D$. flagrans, are available as commercial. Biotechnological products such as nanoparticles and obtaining primary and secondary metabolites have already been obtained from these fungi. Because they have different mechanisms of action, ovicidal and predatory fungi, when used together, can present a complementary and synergistic action in the biological control of helminths. Therefore, future research in the search for new formulations, the association of fungi from different groups, extraction of new molecules, and nanoparticles of these fungi in the control of helminths in various domestic animals are desired.

Keywords: nematophagous fungi; predatory fungi; ovicidal fungi; Duddingtonia flagrans; Pochonia chlamydosporia; Mucor circinelloides

\section{Brief History of Helminthophagous Fungi}

There are many studies from across the world demonstrating the successful implementation of helminthophagous fungi for the biological control of parasites in animal production systems. It should be emphasized, a priori, that the term "helminthophagous fungi" is the best one to use due to the ability and diversified action of these organisms against not only nematodes but also cestodes and trematodes. However, the term nematophagous fungus is still the most used in the scientific literature.

Helminthophagous fungi can be divided into five groups: nematode-trapping/predatorial, opportunistic or ovicidal, endoparasitic, toxin-producing, and producers of special attack devices. The fungi of the first and second groups produce modified hyphae called traps, with which, by a mechanical/enzymatic process, they bind and digest nematode larvae, eggs, cysts, and nematode females [1,2]. Thus, they are the ones that best act in the predation of animal parasites. Supplied orally, after passing through the gastrointestinal tract of animals, fungal structures such as conidia, mycelium, and chlamidospores germinate in the feces, forming a network of hyphae with the ability to capture and destroy infective forms of animal parasitic helminths [3]. 
Since 2014, several studies carried out on an experimental basis have proposed the efficacy of helminthophagous fungi from the predatorial group (Duddingtonia spp., Arthrobotrys spp. and Monacrosporium spp.) and from the ovicidal group (Pochonia chlamydosporia and Mucor circinelloides) against the decrease in the rates of recurrence of helminth infections in different parts of the world [4-10]. In these studies, successful experiments demonstrated the great versatility of helminthophagous fungi in the classic biological control of helminths.

In the last five years, commercial formulations containing D. flagrans started became commercially available. In Brazil (Bioverm ${ }^{\circledR}$ _AC001, GhenVet Saúde Animal, Paulínia, Brazil), Australia, and New Zealand (BioWorma ${ }^{\circledR}$ —NCIMB 30336, BioWorma, Sydney, Australia), these products are already used, with administration in animal feed [8,11-14].

\section{Most Promising Helminthophagous Fungi}

\subsection{Duddingtonia flagrans}

The fungus $D$. flagrans acts as the main predatory fungus of gastrointestinal parasitic nematode larvae. Relevant results were published after using Bioverm ${ }^{\circledR}$ (GhenVet Saúde Animal, Paulínia, Brazil), a commercial product based on D. flagrans (AC001). Bioverm ${ }^{\circledR}$ is licensed by the Brazilian Ministry of Agriculture, Livestock, and Supply, and can be used to combat nematodiosis in domestic animals [8].

Duddingtonia flagrans was classified as "Old friend of researchers", a tribute to the great diversity of action that this fungus has [3]. Over the years, a series of important studies demonstrating the effectiveness of strain AC001 in the production of extracellular enzymes and crude enzymatic extract denoted its ability to be tested against the control of helminth gastrointestinal parasites $[9,15,16]$.

For decades, the good production of chlamydospores (resistant structures) of this fungus has been studied [17] and, therefore, its commercial potential. However, recently, the production of silver nanoparticles (AgNP's) derived from this fungus had an effect on infective larvae of Ancylostoma caninum, the main helminth of dogs and cats [18]. This finding opened new avenues for the use of the fungus and, therefore, new products such as bioanthelmintics may, in the future, be another possibility for a more successful parasite control against the already installed problem of parasitic resistance.

\subsection{Pochonia chamydosporia}

The fungus P. chlamydosporia (Goddard) Zare and Gams (syn. Verticillium chlamydosporium) parasitizes helminth eggs through specialized structures called appressoria, which allow the colonization of the egg surface and penetration by mechanical and enzymatic action $[19,20]$. This fungus also produces chlamydospores in abundance. Several studies have addressed the efficacy of $P$. chlamydosporia in the control of helminths in domestic animals such as Oxyuris equi [21], Ancylostoma ceylanicum, Ascaris suum [22], Fasciola hepatica [23,24], Toxocara canis [25], and in poultry helminths $[15,26,27]$.

There are reports that $P$. chlamydosporia, in addition to ovicidal action, parasitises female phytonematodes of the genus Meloidogyne, which are colonized and completely digested [28,29]. Several secondary metabolites produced by this fungus have been described as promising to be applied as anthelmintics [30,31]. Intermediate hosts of trematodes, such as the mollusk Pseudosuccinea columella, also have their offspring affected by this fungus [32].

Because they have different mechanisms of action, ovicidal and predatory fungi, when used together, can present a complementary and synergistic action in the biological control of helminths [33]. Therefore, the application of this fungus is of substantial importance for the biological control of helminths in domestic animals.

\subsection{Mucor circinelloides}

Another species capable of adhering to the surface of the eggs of certain helminths, penetrating and feeding on their contents, is Mucor circinelloides [34]. It is a filamentous sapro- 
phytic fungus with action against trematode eggs (F. hepatica, Calicophoron daubneyi) [35,36], ascarids (Toxocara canis, Toxascaris leonina, A. suum, Bayliscascaris procyonis) [37,38], and whipworms (Trichuris spp.) [39]. In several investigations it was shown that M. cicinelloides can be cultivated together with $D$. flagrans, with ovicidal and larvicidal activity very practical for the control of helminths whose infective stages are eggs or larvae that develop in the environment [40].

\section{Advances in the Control of Gastrointestinal Nematodes in Pasture Animals}

The internal parasites of ruminants is considered one of the main causes of important economic losses in cattle kept under pasture conditions, mainly in tropical and subtropical regions, due to the conditions of high temperature and humidity [41,42]. The absence of adequate anthelmintic control can lead to significant losses responsible for the decrease in food consumption, gastrointestinal disturbances, and compromised animal development, which can result in death in extreme cases $[43,44]$. In some regions, helminthiasis are the main cause of mortality in goats, sheep, cattle, and horses, especially young animals. The parasitic nematodes are present year-round in pastures [45-47].

The anthelmintic resistance of gastrointestinal nematodes (GIN) has become an emerging problem worldwide [48-53]. Often, anthelmintics are administered without technical criteria for drug selection, empirically and indiscriminately, with additional implications for the efficacy of the products, causing the emergence and spread of anthelmintic resistance $[54,55]$.

In tropical countries, the genera Haemonchus, Cooperia, Trichostrongylus, and Oesophagostomum are the most prevalent GIN in domestic ruminants, causing problems to animal health [55-58]. In horses, small strongyls (cyathostomins) and large strongyls (Strongylus spp.) are the most prevalent [47,59-61].

The free or pre-parasitic life stage of the main GIN of ruminants and horses is directly influenced by climatic variations in temperature, humidity, and rainfall, and the climate should be a major factor in the search for integrated measures for parasite control. The infective stages (L3) of the GIN have a greater rate of survival at the beginning of rainfall periods. However, under conditions of low rainfall associated with relatively mild temperatures, L3 may survive in the feces for extended periods, representing a source of contamination of pastures [41].

It is extremely important to recognize the problems caused by GIN throughout the world, highlighting that parasite control must, above all, start with knowledge about population dynamics and the epidemiology of GIN, their characteristics and main species present in the most diverse types of ruminants and equines productions worldwide. The knowledge of the degree of contamination of pastures by infective strongylide larvae is very useful for epidemiological purposes. It can determine the risk of infection in animals and provide data for the establishment of integrated control programs [45].

In the environment, helminthophagous fungi can survive as saprophytic agents, feeding on environmental organic matter, or as parasites, feeding on a wide variety of free-living helminths [62,63]. Factors such as temperature, humidity, and oxygen, which determine a microclimate favorable to the development of helminth eggs and larvae, also enable fungal survival, making possible the predation of parasites [64-66].

It has been proven that after oral administration of D. flagrans (AC001-Bioverm ${ }^{\circledR}$, GhenVet Saúde Animal, Paulínia, Brazil), at a dosage of $1 \mathrm{~g} / 10 \mathrm{~kg}$ of body weight $\left(10^{5}\right.$ chlamydospores $\left./ \mathrm{g}\right)$, there was fungal survival after passage through the gastrointestinal tract of sheep and cattle, with efficient larval predation in vitro $[8,14]$. Under field conditions, the daily administration of Bioverm ${ }^{\circledR}$ for six months demonstrated a significant parasitic reduction in cattle and horses in Brazil $[12,13]$. The use of biological control by helminthophagous fungi provides an option to reduce the rates of contamination by larvae and, consequently, less reinfection for the animals, enabling them to develop natural immunity against the helminths. In addition, animals that receive helminthophagous fungi have higher weight gain rates, higher globular volume percentages, and lower EPG values 
when compared to those that do not receive the fungi [5,67-70]. In grazing horses that received $D$. flagrans chlamydospores daily, strongylide counts below 200 EPG were obtained for 16 months, also verifying that they recovered normal blood values of erythrocytes, hemoglobin, and hematocrit [71]. With daily administration of a mixture of $M$. circinelloides and $D$. flagrans chlamydospores, a grazing dairy herd was not reinfected by $C$. daubneyi for a period of two years, and the strongylide count in feces was less than 110 EPG. No adverse effects were detected in any animal [72].

\section{Advances and Perspectives for the Control of Geohelminths}

The nematodes A. caninum, T. Canis, and T. cati are potentially zoonotic parasites of dogs and cats in various parts of the world [73-75]. As part of the environmental cycle, these parasites manage to cause infections via soil/environment, giving them the name of geohelminths [76].

The use of anthelmintic drugs is the main form of control used to helminth infections in domestic animals, but cases of therapeutic failure have also been observed, resulting in reports of anthelmintic resistance [77-79]. It is noteworthy that the high environmental resistance of infective A. caninum larvae, T. Canis, and T. cati eggs gives them a greater ability to survive. However, by the use of helminthophagous fungi P. chlamydosporia, the environment can be used as an alternative route for their control $[80,81]$.

In places where there is a high population of stray dogs and cats, the presence of zoonotic parasitic forms in the soil of public squares is a sanitary and environmental problem $[82,83]$. Children are the main affected, as they have the habit of playing on the ground [84]. The soils of public environments can be considered maintenance areas for parasites with zoonotic potential, with difficult environmental control, since restricting the access of animals to these environments is impractical. Common disinfectants such as $2 \%$ sodium hypochlorite (bleach), have highly effective in environmental sanitation, with the destruction of geohelminths in impermeable soils and surfaces. Nonetheless, common disinfectants have limitations of effectiveness on other surfaces, such as sandy soils and lawns $[85,86]$. Research with the purpose of promoting integrative control measures, through the association of chemical and biological control, has been developed and demonstrated satisfactory results $[3,9,40,80,87,88]$. Research should be encouraged to evaluate the associated use of helminthophagous fungi and common disinfectants, enabling their associated use in doses that do not cause fungal inhibition, increasing the use of these fungi.

\section{Biotechnological Advances in the Use of Helminthophagous Fungi}

The understanding of biotechnological advances with the use of helminthophagous fungi can be divided into two main points: predatory action against infective larvae and helminth eggs; and the production of primary and secondary metabolites [89]. In this sense, the predatory activity of helminthophagous fungi and its mechanism of action through traps and/or adhesive nets has long been recognized [19,90-93]. For this reason, the use of fungal mixtures with complementary activity (ovicide and larvicide) is of great importance. Furthermore, this mixture of fungi resists the process of manufacturing nutritional pellets and, therefore, represents a very useful formulation for the control of different helminths that affect domestic animals in grazing and wild animals in captivity [40,94].

The production of extracellular enzymes is important for understanding the mechanical and enzymatic process carried out by helminthophagous fungi, especially those classified as ovicides [89]. Through biochemical and molecular studies, it was found that there was a great possibility that these fungi produce extracellular enzymes with direct use against nematode larvae and eggs [95].

The enzymatic activity of nematophagous fungi has motivated great interest in studies in different countries. For example, in China, a recombinant protein from the species Arthrobotrys oligospora, one of the most widely studied nematode-trapping fungi, has been demonstrated to have a high chitinase activity and is able to degrade chitine from both 
infective stages and the egg-shell of the following helminth species Strongylus equinus, Caenorhabditis elegans, and Haemonchus contortus and also the egg-shell of the trematodes F. hepatica and Dicrocoelium chinensis [96].

Thus, research has advanced, and, recently, a new possibility of using these fungi in the control of nematodes was discovered through nanoparticles (NP's) biosynthesized from fungal filtrate [97]. It has been proven that nanoparticles biosynthesized by $D$. flagrans, were able to cause the destruction of infective larvae of $A$. caninum [18].

The biosynthesis of these nanoparticles by filamentous fungi has attracted considerable interest for the use of these microorganisms in the production of NP's, due to their ability to grow on low-cost, nutrient-poor substrates and to produce secondary metabolites. In addition, fungal mycelium can withstand flow pressure, agitation, and other laboratory conditions important for large-scale production. Still, in biological synthesis using fungi, the biosynthesis of NP's occurs extracellularly. That is, the reduction occurs outside the cell, eliminating the need for extra steps to coat the NP's in post-production [98].

Helminthophagous fungi can also produce ecological silver nanoparticles (AgNP's) $[18,97,99]$. They convert toxic metal ions into non-toxic nanoparticles through their catalytic effect [100]. The destruction of L3 of equine cyatostomine nematodes by AgNP's-D. flagrans, with nematicidal effect in $24 \mathrm{~h}$, was a great advance for a new use of these fungus [9].

In the fungus P. chlamidosporia, the secondary metabolite ketamine showed excellent efficacy against $A$. ceylanicum and A. suum and with similar efficacy to the anthelmintic albendazole [31]. Therefore, future research in the search for new formulations, association of fungi from different groups, extraction of new molecules and nanoparticles are desired.

Regarding the study of nematocidal activity of nematophagous fungi metabolites, most research studies have been focused on assessing the nematocidal activity of these molecules against nematodes of importance in agriculture, and there is only scarce information about nematophagous fungi products against parasitic nematodes of impact in the area of animal production. Thus, this is an opportunity to explore this wide and promising field of research to find other biotechnological uses and applications of nematophagous fungi to benefit farmers all over the world.

Author Contributions: Conceptualization, J.V.A., F.R.B., P.M.-d.-G., A.P.-S. and V.L.R.V.; methodology, J.V.A. and V.L.R.V.; investigation, J.V.A., F.R.B., P.M.-d.-G., A.P.-S. and V.L.R.V.; resources, J.V.A.; data curation, V.L.R.V.; writing-original draft preparation, J.V.A., F.R.B., P.M.-d.-G., A.P.-S. and V.L.R.V.; writing-review and editing, V.L.R.V.; visualization, V.L.R.V.; supervision, J.V.A. and V.L.R.V.; funding acquisition, J.V.A. All authors have read and agreed to the published version of the manuscript.

Funding: The authors would like to thank CNPq (National Council for Scientific and Technological Development), Brazil, for the fellowship to J.V.A. and F.R.B.; FAPES (Fundação de Amparo à Pesquisa do Espírito Santo) and FAPEMIG (Fundação de Amparo à Pesquisa do Estado de Minas Gerais), for the financial support.

Institutional Review Board Statement: Not applicable.

Informed Consent Statement: Not applicable.

Data Availability Statement: Not applicable.

Conflicts of Interest: The authors declare no conflict of interest.

\section{References}

1. Liu, X.; Xiang, M.; Che, Y. The living strategy of nemathophagous fungi. Mycoscience 2009, 50, 20-25. [CrossRef]

2. Soares, F.E.F.; Sufiate, B.L.; Queiroz, J.H. Nemathophagous fungi: Far beyond the endoparasite, predator and ovicidal groups. Agric. Nat. Resour. 2018, 52, 1-8. [CrossRef]

3. Braga, F.R.; Araújo, J.V. Nematophagous fungi for biological control of gastrintestinal nematodes in domestic animals. Appl. Microbiol. Biotechnol. 2014, 98, 71-82. [CrossRef] [PubMed]

4. Saumell, C.A.; Fernández, A.S.; Fusé, L.A.; Rodríguez, M.; Sagüés, M.F.; Iglesias, L.E. Nematophagous fungi from decomposing cattle faeces in Argentina. Rev. Iberoam. Micol. 2015, 32, 252-256. [CrossRef] 
5. Vilela, V.L.R.; Feitosa, T.F.; Braga, F.R.; Araújo, J.V.; Santos, A.; Morais, D.F.; Souto, D.V.O.; Athayde, A.C.R. Coadministration of nematophagous fungi for biological control over gastrointestinal helminths in sheep in the semiarid region of northeastern Brazil. Vet. Parasitol. 2016, 221, 139-143. [CrossRef]

6. Mendoza-de-Gives, P.; López-Arellano, M.E.; Aguilar-Marcelino, L.; Olazarán-Jenkins, S.; Reyes-Guerrero, D.; Ramírez-Várgas, G.; Veja-Murilloc, V.E. The nematophagous fungus Duddingtonia flagrans reduces the gastrointestinal parasitic nematode larvae population in faeces of orally treated calves maintained under tropical conditions-Dose/response assessment. Vet. Parasitol. 2018, 263, 66-72. [CrossRef]

7. Costa, P.W.L.; Alvares, F.B.V.; Bezerra, R.A.; Sarmento, W.F.; Silva, F.F.; Rodrigues, J.A.; Feitosa, T.F.; Araújo, J.V.; Braga, F.R.; Vilela, V.L.R. Effect of refrigeration storage of nemathophagous fungi embedded in sodium alginate pellets on predatory activity against asinine gastrointestinal nematodes. Biocontrol. Sci. Technol. 2019, 29, 1-18. [CrossRef]

8. Braga, F.R.; Ferraz, C.M.; Silva, E.M.; Araújo, J.V. Efficiency of the Bioverm ${ }^{\circledR}$ (Duddingtonia flagrans) fungal formulation to control in vivo and in vitro of Haemonchus contortus and Strongyloides papillosus in sheep. 3 Biotech 2020, 10, 62. [CrossRef]

9. Ferraz, C.M.; Silva, L.P.C.; Soares, F.E.F.; Souza, R.L.O.; Tobias, F.L.; Araújo, J.V.; Veloso, F.B.R.; Laviola, F.P.; Endringer, D.C.; Mendoza-de-Gives, P.; et al. Effect of silver nanoparticles (AgNP's) from Duddingtonia flagrans on cyathostomins larvae (subfamily: Cyathostominae). J. Invertebr. Pathol. 2020, 1, 107395. [CrossRef]

10. Rodrigues, J.A.; Alvares, F.B.V.; Silva, J.T.; Ferreira, L.C.; Costa, P.W.L.; Sarmento, W.F.; Feitosa, T.F.; Araujo, J.V.; Braga, F.R.; Vilela, V.L.R. Predatory effects of the fungus Arthrobotrys cladodes on sheep gastrointestinal nematodes. Biocontrol. Sci. Technol. 2020, 1-10. [CrossRef]

11. Bampidis, V.; Azimonti, G.; Bastos, M.L.; Christensen, H.; Dusemund, B.; Kos Durjava, M.; Kouba, M.; López-Alonso, M.; López Puente, S.; Marcon, F.; et al. Scientific opinion on the safety and efficacy of BioWorma ${ }^{\circledR}$ (Duddingtonia flagrans NCIMB 30336) as a feed additive for all grazing animals. EFSA J. 2020, 18, 6208. [CrossRef]

12. Oliveira, L.S.S.C.B.; Dias, F.G.S.; Melo, A.L.T.; Carvalho, L.M.; Silva, E.N.; Araújo, J.V. Bioverm ${ }^{\circledR}$ in the control of nematodes in beef cattle raised in the Central-West region of Brazil. Pathogens 2021, 10, 548. [CrossRef]

13. Fausto, G.C.; Fausto, M.C.; Vieira, Í.S.; Freitas, S.G.; Carvalho, L.M.; Oliveira, I.C.; Silva, E.N.; Campos, A.K.; Araújo, J.V. Formulation of the nematophagous fungus Duddingtonia flagrans in the control of equine gastrointestinal parasitic nematodes. Vet. Parasitol. 2021, 296, 109458-109464. [CrossRef]

14. Rodrigues, J.A.; Roque, F.L.; Alvares, F.B.V.; Silva, A.L.P.; Lima, E.F.; Silva Filho, G.M.; Feitosa, T.F.; Araujo, J.V.; Braga, F.R.; Vilela, V.L.R. Efficacy of a commercial fungal formulation containing Duddingtonia flagrans (Bioverm ${ }^{\circledR}$ ) for controlling bovine gastrointestinal nematodes. Rev. Bras. Parasitol. Veter. 2021, 30, e026620. [CrossRef]

15. Braga, F.R.; Araújo, J.V.; Araujo, J.M.; Frassy, L.N.; Tavela, A.O.; Soares, F.E.F.; Carvalho, R.O.; Queiroz, L.M.; Queiroz, J.H. Pochonia chlamydosporia fungal activity in a solid medium and its crude extract against eggs of Ascaridia galli. J. Helminthol. 2012, 86, 348-352. [CrossRef]

16. Braga, F.R.; Soares, F.E.F.; Giuberti, T.Z.; Lopes, A.D.C.G.; Lacerda, T.; Ayupe, T.H.; Queiroz, P.V.; Gouveia, A.S.; Pinheiro, L.; Araújo, A.L.; et al. Nematocidal activity of extracellular enzymes produced by the nematophagous fungus Duddingtonia flagrans on cyathostomin infective larvae. Vet. Parasitol. 2015, 212, 214-218. [CrossRef]

17. Silva, M.E.; Araújo, J.V.; Braga, F.R.; Soares, F.E.F.; Rodrigues, D.S. Control of infective larvae of gastrointestinal nematodes of heifers by isolates of the nematophagous fungi. Rev. Bras. Parasitol. Vet. 2013, 26, 1-6. [CrossRef]

18. Barbosa, A.C.M.S.; Silva, L.P.C.; Ferraz, C.M.; Tobias, F.L.; Araújo, J.V.; Loureiro, B.; Braga, G.M.A.M.; Veloso, F.B.R.; Soares, F.E.F.; Fronza, M.; et al. Nematicidal activity of silver nanoparticles from the fungus Duddingtonia flagrans. Int. J. Nanomed. 2019, 14, 2341-2348. [CrossRef]

19. Braga, F.R.; Araújo, J.V.; Campos, A.K.; Araujo, J.M.; Silva, A.S.; Carvalho, R.O.; Tavela, A.O. In vitro evaluation of the action of the nematophagous fungi Duddingtonia flagrans, Monacrosporium sinense and Pochonia chlamydosporia on Fasciola hepatica eggs. World J. Microbiol. Biotechnol. 2008, 24, 1559-1564. [CrossRef]

20. Dallemole-Giaretta, R.; Freitas, L.G.; Caixeta, L.B.; Xavier, D.M.; Ferraz, S.; Fabry, C.F.S. Produção de clamidósporos de Pochonia chlamydosporia em diferentes substratos. Ciênc. Agrotec. 2011, 35, 314-321. [CrossRef]

21. Braga, F.R.; Araújo, J.V.; Silva, A.R.; Carvalho, R.O.; Araújo, J.M.; Ferreira, S.R.; Carvalho, G.R. Viability of the nematophagous fungus Pochonia chlamydosporia after passage through the gastrointestinal tract of horses. Vet. Parasitol. 2010, 168, 264-268. [CrossRef] [PubMed]

22. Ferreira, S.R.; Araújo, J.V.; Braga, F.R.; Araújo, J.M.; Frassy, L.N.; Ferreira, A.S. Biological control of Ascaris suum eggs by Pochonia chlamydosporia fungus. Vet. Res. Commun. 2011, 35, 553-558. [CrossRef]

23. Dias, A.S.; Araújo, J.V.; Braga, F.R.; Puppin, A.C.; Perboni, W.R. Pochonia chlamydosporia in the biological control of Fasciola hepatica in cattle in Southeastern Brazil. Parasitol. Res. 2013, 112, 2131-2136. [CrossRef]

24. Castro, L.S.; Martins, I.V.F.; Alves, V.; Roldi, F.; Tavares, G.P.; Araújo, J.V. Effect of the enzymatic fungal extract of Pochonia chlamydosporia on the viability of Fasciola hepatica eggs. J. Adv. Vet. Anim. Res. 2020, 10, 135-140.

25. Araujo, J.M.; Araújo, J.V.; Braga, F.R.; Ferreira, S.R.; Tavela, A.O. Predatory activity of chlamydospores of the fungus Pochonia chlamydosporia on Toxocara canis eggs under laboratory conditions. Rev. Bras. Parasitol. Vet. 2013, 22, 171-174. [CrossRef]

26. Thapa, S.; Hinrichsen, L.K.; Brenninkmeyer, C.; Gunnarsson, S.; Heerkens, J.L.T.; Verner, C.; Niebuhr, K.; Willett, A.; Grilli, G.; Thamsborg, S.M.; et al. Prevalence and magnitude of helminth infections in organic laying hens (Gallus gallus domesticus) across Europe. Vet. Parasitol. 2015, 214, 118-124. [CrossRef] 
27. Valadão, M.C.; Carvalho, L.M.; Vieira, Í.S.; Neves, P.H.; Ferreira, V.M.; Campos, A.K.; Soares, F.E.F.; Ferraz, C.M.; Vilela, V.L.R.; Braga, F.R.; et al. Germination capacity of the Pochonia chlamydosporia fungus after its passage through the gastrointestinal tract of domestic chickens (Gallus gallus domesticus). Exp. Parasitol. 2020, 215, 107936-107940. [CrossRef]

28. Podestá, G.S.; Dallemole-Giaretta, R.; Freitas, L.G.; Lopes, E.A.; Ferraz, S.; Zooca, R.J.F. Atividade nematófaga de Pochonia chlamydosporia em solo natural ou autoclavado sobre Meloidogyne javanica. Nematol. Brasileira 2009, 33, 191-193.

29. Zouhar, M.; Douda, O.; Novotny, D.; Novakova, J.; Mazakova, J. Evaluation of the pathogenicity of selected nematophagous fungi. Czech Mycol. 2010, 61, 139-147. [CrossRef]

30. Niu, X.M. Secondary metabolites from Pochonia chlamydosporia and other species of Pochonia. In Perspectives in Sustainable Nematode Management through Pochonia Chlamydosporia Applications for Root and Rhizosphere Health; Manzanilla-López, R.H., Lopez-Llorca, L.V., Eds.; Springer: Berlin/Heidelberg, Germany, 2017; p. 309. [CrossRef]

31. Ferreira, S.R.; Machado, A.R.T.; Furtado, L.F.; Gomes, J.H.S.; Almeida, R.M.; Oliveira, M.T.; Maciel, V.N.; Barbosa, F.S.; Carvalho, L.M.; Bueno, L.L.; et al. Ketamine can be produced by Pochonia chlamydosporia: An old molecule and a new anthelmintic? Parasit. Vectors 2020, 13, 527-531. [CrossRef]

32. Castro, L.S.; Martins, I.V.F.; Menezes, T.V.; Araújo, J.V.; Tunholi-Alves, M.V.; Bittencourt, V.R.E.P. Ovicidal potential of Pochonia chlamydosporia isolate Pc-10 (Ascomycota: Sordariomycetes) on egg masses of the snail Pseudosuccinea columella (Mollusca: Gastropoda). J. Invert. Pathol. 2019, 166, 107212-107217. [CrossRef]

33. Ayupe, T.H.; Monteiro, T.S.A.; Braga, F.R.; Soares, F.E.F.; Mello, I.N.K.; Araujo, J.M.; Freitas, L.G.; Araújo, J.V. Assessment of compatibility between the nematophagous fungi Arthrobotrys robusta and Duddingtonia flagrans under laboratory conditions. Rev. Iberoam. Micol. 2016, 33, 129-130. [CrossRef] [PubMed]

34. Arias, M.S.; Cazapal-Monteiro, C.F.; Suárez, J.; Miguélez, S.; Francisco, I.; Arroyo, F.L.; Suárez, J.L.; Paz-Silva, A.; SánchezAndrade, R.; De Gives, P.M. Mixed production of filamentous fungal spores for preventing soil-transmitted helminth zoonoses: A preliminary analysis. Biomed Res. Int. 2013, 567876. [CrossRef] [PubMed]

35. Cortiñas, F.J.; Cazapal-Monteiro, C.F.; Hernández, J.A.; Arroyo, F.L.; Miguélez, S.; Suárez, J.; de Arellano, M.E.L.; SánchezAndrade, R.; de Gives, P.M.; Paz-Silva, A.; et al. Potential use of Mucor circinelloides for the biological control of certain helminths affecting livestock reared in a care farm. Biocontrol Sci. Technol. 2015, 25, 1443-1452. [CrossRef]

36. Arroyo, F.; Hernández, J.A.; Cazapal-Monteiro, C.F.; Pedreira, J.; Sanchís, J.; Romasanta, Á.; Sánchez-Andrade, R.; Paz-Silva, A.; Arias, M.S. Effect of the filamentous fungus Mucor circinelloides on the development of eggs of the rumen fluke Calicophoron daubneyi (Paramphistomidae). J. Parasitol. 2017, 103, 199-206. [CrossRef] [PubMed]

37. Cazapal-Monteiro, C.F.; Hernández, J.A.; Arroyo, F.L.; Miguélez, S.; Romasanta, Á.; Paz-Silva, A.; Sánchez-Andrade, R.; Arias, M.S. Analysis of the effect of soil saprophytic fungi on the eggs of Baylisascaris procyonis. Parasitol. Res. 2015, 114, 2443-2450. [CrossRef]

38. Hernández, J.A.; Cazapal-Monteiro, C.F.; Sanchís, J.; Sánchez-Andrade, R.; Paz-Silva, A.; Arias, M.S. Potential usefulness of filamentous fungi to prevent zoonotic soil-transmitted helminths. Vector Borne Zoon. Dis. 2018, 18, 690-696. [CrossRef]

39. Hernández, J.A.; Cazapal-Monteiro, C.F.; Arroyo, F.L.; Silva, M.I.; Palomero, A.M.; Paz-Silva, A.; Sánchez-Andrade, R.; Arias, M.S. Biological control of soil transmitted helminths (STHs) in a zoological park by using saprophytic fungi. Biol. Control. 2018, 122, 24-30. [CrossRef]

40. Hernández, J.A.; Sánchez-Andrade, R.; Cazapal-Monteiro, C.F.; Arroyo, F.L.; Sanchís, J.M.; Paz-Silva, A.; Arias, M.S. A combined effort to avoid strongyle infection in horses in an oceanic climate region: Rotational grazing and parasiticidal fungi. Parasite Vector 2018, 11, 240. [CrossRef]

41. Almeida, L.R.; Castro, A.A.; Silva, F.B.M.; Fonseca, A.H. Desenvolvimento, sobrevivência e distribuição de larvas infectantes de nematóides gastrintestinais de ruminantes na estação seca da Baixada Fluminense, RJ. Rev. Bras. Parasitol. Vet. 2005, 14, 89-94.

42. Arsenopoulos, K.V.; Fthenakis, G.C.; Katsarou, E.I.; Papadopoulos, E. Haemonchosis: A challenging parasitic infection of sheep and goats. Animals 2021, 11, 363. [CrossRef]

43. Cezar, A.S.; Catto, J.B.; Bianchin, I. Controle alternativo de nematódeos gastrintestinais dos ruminantes: Atualidade e perspectivas. Ciênc. Rural. 2008, 38, 2083-2091. [CrossRef]

44. Almeida, A.C.D.F.; Chagas, J.D.R.; Ávila, L.M.; Marques, T.L.P.; Moraes, R.F.F.; Gomes, L.P.M.; Roier, E.C.R.; Baêta, B.A. Diagnóstico e controle químico das helmintoses em bovinos: Revisão de literatura. Res. Soc. Dev. 2020, 9, e4089119908. [CrossRef]

45. Vieira, V.D.; Riet-Correa, W.; Vilela, V.L.R.; Medeiros, M.A.; Batista, J.A.; Melo, L.R.B.; Santos, A.; Riet-Correa, F. Controle de parasitas gastrintestinais em ovinos e análise financeira de uma fazenda com sistema de pastejo rotacionado irrigado no semiárido nordestino. Pesq. Veter. Bras. 2018, 38, 913-919. [CrossRef]

46. Vilela, V.L.R.; Bezerra, H.M.F.F.; Bezerra, R.A.; Dantas, M.O.; Alcantara, E.T.; Oliveira, L.V.S.; Nobrega, K.S.; Calazans, F.B.; Braga, F.R.; Molento, M.B. Sustainable agriculture: The use of FAMACHA method in Santa Ines sheep in the Semi-arid region of Brazil. Semin. Ciênc. Agrár. 2021, 42, 1647-1662. [CrossRef]

47. Molento, M.B.; Vilela, V.L.R. Health evaluation of donkeys: Parasite control methods and a model for challenge infections. Braz. J. Vet. Res. Anim. Sci. 2021, 58, e174275. [CrossRef]

48. Lobayan, S.I.; Schapiro, J.H.; Fiel, C.A.; Zabalo, M.M.; Roselli, J.G. Resistencia a los antihelmínticos en bovinos del nordeste de Corrientes (Argentina). Rev. Vet. 2017, 28, 138-140. [CrossRef]

49. Silva, F.F.; Bezerra, H.M.F.F.; Feitosa, T.F.; Vilela, V.L.R. Nematode resistance to five anthelmintic classes in naturally infected sheep herds in Northeastern Brazil. Rev. Bras. Parasitol. Vet. 2018, 27, 423-429. [CrossRef] 
50. Baiak, B.H.; Lehnen, C.B.; Rocha, R.A. Anthelmintic resistance of injectable macrocyclic lactones in cattle: A systematic review and meta-analysis. Rev. Bras. Parasitol. Vet. 2019, 28, 59-67. [CrossRef] [PubMed]

51. Kaplan, R.M. Biology, epidemiology, diagnosis, and management of anthelmintic resistance in gastrointestinal nematodes of livestock. Vet. Clin. N. Am. Food Anim. Pract. 2020, 36, 17-30. [CrossRef] [PubMed]

52. Hildreth, M.B.; McKenzie, J.B. Epidemiology and control of gastrointestinal nematodes of cattle in northern climates. Vet. Clin. North Am. Food Anim. Pract. 2020, 36, 59-71. [CrossRef] [PubMed]

53. Minguetto, J.G.M.; Bogado, A.L.G.; Okano, W.; Cunha Filho, L.F.C.; Silva, L.C.; Zanol, D.; Ferraz, C.M.; Moreira, T.F.; Tobias, F.L.; Braga, F.R.; et al. Biological control of gastrointestinal nematodes in young ewes treated with fungi. Biocontrol. Sci. Technol. 2021, 31, 1-13. [CrossRef]

54. Neves, J.H.; Carvalho, N.; Rinaldi, L.; Cringoli, G.; Amarante, A.F.T. Diagnosis of anthelmintic resistance in cattle in Brazil: A comparison of different methodologies. Vet. Parasitol. 2014, 206, 216-226. [CrossRef]

55. Ramos, F.; Marques, C.B.; Reginato, C.Z.; Bräunig, P.; Osmari, V.; Fernandes, F.; Sangioni, L.A.; Vogel, F.S.F. Field and molecular evaluation of anthelmintic resistance of nematode populations from cattle and sheep naturally infected pastured on mixed grazing areas at Rio Grande do Sul, Brazil. Acta Parasitol. 2019, 65, 118-127. [CrossRef]

56. Vieira, V.D.; Feitosa, T.F.; Vilela, V.L.R.; Azevedo, S.S.; Neto, J.L.A.; Morais, D.F.; Ribeiro, A.R.C.; Athayde, A.C.R. Prevalence and risk factors associated with goat gastrointestinal helminthiasis in the Sertão region of Paraíba State, Brazil. Trop. Anim. Health Prod. 2014, 46, 355-361. [CrossRef]

57. Vieira, V.D.; Vilela, V.L.R.; Feitosa, T.F.; Athayde, A.C.R.; Azevedo, S.S.; Souto, D.V.O.; Silveira, G.L.; Melo, L.R.B. Sheep gastrointestinal helminthiasis in the Sertão region of Paraíba State, Northeastern Brazil: Prevalence and risk factors. Rev. Bras. Parasitol. Veter. 2014, 23, 488-494. [CrossRef]

58. Silva, W.W.; Delfino, L.J.B.; Medeiros, M.C.; Silva, J.P. Multiple resistances of gastrointestinal nematodes to anthelmintic groups incattle of semiarid of Paraíba, Brazil. Acta Bras. 2017, 1, 29-32. [CrossRef]

59. Attia, M.M.; Khalifa, M.M.; Atwa, M.T. The prevalence and intensity of external and internal parasites in working donkeys (Equus asinus) in Egypt. Vet. World. 2018, 11, 1298-1306. [CrossRef]

60. Costa, P.W.L.; Feitosa, T.F.; Vilela, V.L.R. Parasitic profile of traction equids in the semi-arid climate of Paraíba State, Northeastern, Brazil. Rev. Bras. Parasitol. Vet. 2018, 27, 218-222. [CrossRef]

61. Gianfaldoni, C.; Barlozzari, G.; Mancini, S.; Di Domenico, E.; Maestrini, M.; Perrucci, S. Parasitological investigation in an organic dairy donkey farm. Large Anim. Rev. 2020, 26, 25-30.

62. Saxena, G.; Mittal, T. Trap formation by conidia of nematode trapping Monacrosporium thaumasium spp. Mycol. Res. 1995, 7, 839-840. [CrossRef]

63. Larsen, M. Biological control of helminths. Int. J. Parasitol. 1999, 29, 139-146. [CrossRef]

64. Mota, M.A.; Campos, A.K.; Araújo, J.V. Controle biológico de helmintos parasitos de animais por fungos nematófagos. Rev. Bras. Parasitol. Veter. 2003, 13, 165-170. [CrossRef]

65. Vilela, V.L.R.; Feitosa, T.F.; Braga, F.R.; Araújo, J.V.; Souto, D.V.O.; Santos, H.E.S.; Athayde, A.C.R. Biological control of goat gastrointestinal helminthiasis by Duddingtonia flagrans in a semi-arid region of the Northeastern Brazil. Vet. Parasitol. 2012, 188, 127-133. [CrossRef] [PubMed]

66. Vilela, V.L.R.; Feitosa, T.F.; Braga, F.R.; Araújo, J.V.; Lucena, S.C.; Dantas, E.S.; Athayde, A.C.R.; Silva, A.R. Effect of Monacrosprorium thaumasium in the control of the goat gastrointestinal helminthiasis in the semi-arid of Brazil. Parasitol. Res. 2013, 112, 871-877. [CrossRef] [PubMed]

67. Silveira, W.F.; Oliveira, G.D.; Silva, L.A.; Carvalho, L.M.; Braga, F.R.; Zanuncio, J.C.; Araújo, J.V. Predation rate of nematophagous fungi after passing through the gastrointestinal tract of goats. Small Ruminant Res. 2017, 101-105. [CrossRef]

68. Vilela, V.L.R.; Feitosa, T.F.; Braga, F.R.; Vieira, V.D.; Lucena, S.C.; Araújo, J.V. Control of sheep gastrointestinal nematodes using the combination of Duddingtonia flagrans and Levamisole Hydrochloride 5\%. Rev. Bras. Parasitol. Veter. 2018, 27, 26-31. [CrossRef]

69. Vilela, V.L.R.; Feitosa, T.F.; Braga, F.R.; Santos, A.; Bezerra, R.A.; Silva, G.L.L.; Athayde, A.C.R.; Araujo, J.V. Use of Duddingtonia flagrans in the control of gastrointestinal nematodes of feedlot goats. Semin. Ciênc. Agrár. 2020, 41, 915-924. [CrossRef]

70. Baiak, B.H.B.; Gasparina, J.M.; Ianke, L.; Sousa, K.T.; Deniz, M.; Pereira, L.M.; Araújo, J.V.; Rocha, R.A.; Dittrich, J.R. Predatory activity of nematophagus fungus Duddingtonia flagrans in infective larvae after gastrointestinal transit: Biological control in pasture areas and in vitro. J. Helminthol. 2021, 95, 1-8. [CrossRef]

71. Hernández, J.A.; Arroyo, F.L.; Suárez, J.; Cazapal-Monteiro, C.; Romasanta, A.; López-Arellano, M.E.; Pedreira, J.; Madeira de Carvalho, L.M.; Sánchez-Andrade, R.; Arias, M.S.; et al. Feeding horses with industrially manufactured pellets with fungal spores to promote nematode integrated control. Vet. Parasitol. 2016, 229, 37-44. [CrossRef] [PubMed]

72. Voinot, M.; Cazapal-Monteiro, C.; Hernández, J.Á.; Palomero, A.M.; Arroyo, F.L.; Sanchís, J.; Pedreira, J.; Sánchez-Andrade, R.; Paz-Silva, A.; Arias, M.S. Integrating the control of helminths in dairy cattle: Deworming, rotational grazing and nutritional pellets with parasiticide fungi. Vet. Parasitol. 2020, 278, 109038. [CrossRef] [PubMed]

73. Macpherson, C.N.L. The epidemiology and public health importance of toxocariasis: A zoonosis of global importance. Int. J. Parasitol. 2013, 43, 999-1008. [CrossRef]

74. Overgaauw, P.A.M.; Van Knapen, F. Veterinary and public health aspects of Toxocara spp. Vet. Parasitol. 2013, 193, 398-403. [CrossRef] [PubMed] 
75. Chen, J.; Liu, Q.; Liu, G.H.; Zheng, W.B.; Hong, S.J.; Sugiyama, H.; Zhu, X.Q.; Elsheikha, H.M. Toxocariasis: A silent threatwith a progressive public health impact. Infect. Dis. Pover. 2018, 7, 59. [CrossRef] [PubMed]

76. Lim-Leroy, A.; Chua, T.H. Prevalence and risk factors of geohelminthiasis among the rural village children in Kota Marudu, Sabah, Malaysia. PLoS ONE 2020, 15, e0239680. [CrossRef] [PubMed]

77. Kopp, S.R.; Kotze, A.C.; Mccarthy, J.S.; Coleman, G.T. High-level pyrantel resistance in the hookworm Ancylostoma caninum. Vet. Parasitol. 2007, 143, 299-304. [CrossRef]

78. Sunderkötter, C.; Stebut, E.V.; Schöfer, H.; Mempel, M.; Reinel, D.; Wolf, G.; Meyer, V.; Nast, A.; Burchard, G. S1 guideline diagnosis and therapy of cutaneous larva migrans (creeping disease). J. Dtsch. Dermatol. Ges. 2014, 12, 86-91. [CrossRef]

79. Jimenez-Castro, P.D.J.; Howel, S.B.; Schaefer, J.J.; Avramenko, R.W.; Gilleard, J.S.; Kaplan, R.M. Multiple drug resistance in the canine hookworm Ancylostoma caninum: An emerging threat? Parasit. Vectors 2019, 12, 576. [CrossRef]

80. Frassy, L.N.; Braga, F.R.; Silva, A.R.; Araújo, J.V.; Ferreira, S.R.; Freitas, L.G. Destruição de ovos de Toxocara canis pelo fungo nematófago Pochonia chlamydosporia. Rev. Soc. Bras. Med. Trop. 2010, 43, 102-104. [CrossRef]

81. Ursache, A.L.; Mirean, V.; Dumitrache, M.; Andrei, L.; Stefanut, L.; Cozma, V.; Catana, R.; Cernea, M. Is routine disinfection effincient in preventing contamination with Toxocara canis eggs? J. Helmintol. 2019, 12, e60. [CrossRef]

82. Batista, S.P.; Silva, F.F.; Valencio, B.A.; Carvalho, G.M.M.; Santos, A.; Costa, F.T.R.; Feitosa, T.F.; Vilela, V.L.R. Parasitos zoonóticos em solos de praças públicas no município de Sousa, Paraíba. Rev. Bras. Ciênc. Veter. 2019, 26, 82-86. [CrossRef]

83. Gorgônio, S.A.; Sousa, D.L.C.; Bezerra, C.S.; Monteiro, G.D.F.; Paulo, F.S.; Costa, P.W.L.; Alexandre, J.A.F.; Silva, W.W.; Vilela, V.L.R.; Feitosa, T.F.; et al. Agentes parasitários de importância em Saúde Única em solos de praças públicas em condições semiáridas. Res. Soc. Dev. 2021, 10, e51810111970. [CrossRef]

84. Martins, R.S.; Alves, V.M.T. Análises de areia de parques públicos nos munícipios de Castelo e Cachoeiro de Itapemirim, Espirito Santo. PubVet 2018, 12, 1-9. [CrossRef]

85. Morrondo, P.; Diez-Morrondo, C.; Pedreira, J.; Diez-Baños, N.; Sánchez-Andrade, R.; Paz-Silva, A.; Diéz-Baños, P. Toxocara canis larvae viability after disinfectant-exposition. Parasitol. Res. 2006, 99, 558-561. [CrossRef] [PubMed]

86. Verocai, G.G.; Tavares, P.V.; Ribeiro, F.A.; Correia, T.R.; Scott, F.B. Effects of disinfectants on Toxocara canis embryogenesis and larval establishment in mice tissues. Zoonoses Public Health 2010, 57, e213-e216. [CrossRef] [PubMed]

87. Braga, F.R.; Carvalho, R.O.; Araujo, J.M.; Silva, A.R.; Araújo, J.V.; Lima, W.S.; Tavela, A.O.; Rodrigo, S.F. Predatory activity of the fungi Duddingtonia flagrans, Monacrosporium thaumasium, Monacrosporium sinense and Arthrobotrys robusta on Angiostrongylus vasorum first stage larvae. J. Helminthol. 2009, 83, 303-308. [CrossRef] [PubMed]

88. Lima, J.A.C.; Ferraz, C.M.; Sobral, S.A.; Geniêr, H.L.A.; Soares, F.E.F.; Loureiro, D.B., Jr.; Lima, M.R.; Araújo, J.V.; Tobias, F.L.; Vilela, V.L.R.; et al. Combined use of chemical and biological compounds to control hookworm. J. Helminthol. 2020, 94, 1-4. [CrossRef] [PubMed]

89. Soares, F.E.F.; Queiróz, J.H.; Araújo, J.V.; Rodrigues, M.G.R.; Tavela, A.O.; Aguiar, A.R.; Lacerda, T.; Ferraz, C.M.; Rangel, M.C.V.; Sena, T.; et al. Action of proteases of the nematophagous fungi Pochonia chlamydosporia on Ascaris suum eggs of collared peccary (Pecari tajacu). Afr. J. Microbiol. Res. 2015, 9, 1833-1886. [CrossRef]

90. Araujo, J.V.; Santos, M.A.; Ferraz, S.; Maia, A.S. Antagonistic effect of predacious fungi Arthrobotrys on infective Haemonchus placei larvae. J. Helminthol. 1993, 67, 136-138. [CrossRef]

91. Mendoza-de-Gives, P.; Davies, K.G.; Clarck, S.J.; Behnke, J.M. Predatory behaviour of trapping fungi against srf mutants of Caenorhabditis elegans and different plant and animal parasitic nematodes. Parasitology 1999, 119, 95-104. [CrossRef]

92. Lysek, H.; Fassatiová, O.; Pineda, N.C.; Hernández, N.L. Ovicidal fungi in soils of Cuba. Folia Parasitol. 1982, 29, 265-270.

93. Braga, F.R.; Araújo, J.V.; Campos, A.K.; Silva, A.R.; Araujo, J.M.; Carvalho, R.O.; Correa, D.N.; Pereira, C.A.J. In vitro evaluation of the effect of the nematophagous fungi Duddingtonia flagrans, Monacrosporium sinense and Pochonia chlamydosporia on Schistosoma mansoni eggs. World J. Microbiol. Biotechnol. 2008, 24, 2713-2716. [CrossRef]

94. Palomero, A.M.; Cazapal-Monteiro, C.F.; Valderrábano, E.; Paz-Silva, A.; Sánchez-Andrade, R.; Arias, M.S. Soil fungi enable the control of gastrointestinal nematodes in wild bovidae captive in a zoological park: A 4-year trial. Parasitology 2020, 147, 791-798. [CrossRef] [PubMed]

95. Braga, F.R.; Araujo, J.M.; Silva, A.R.; Araújo, J.V.; Carvalho, R.O.; Soares, F.E.F.; Queiroz, J.H.; Geniêr, H.L.A. Ovicidal action of a crude enzymatic extract of fungus Pochonia chlamydosporia against Ancylostoma sp eggs. Rev. Soc. Bras. Med. Trop. 2011, 44, 116-118. [CrossRef] [PubMed]

96. Zhong, W.; Chen, Y.; Gong, S.; Qiao, J.; Meng, Q.; Zhang, X.; Wang, X.; Huang, Y.; Tian, L.; Niu, Y. Enzymological properties and nematode-degrading activity of recombinant chitinase AO-379 of Arthrobotrys oligospora. Kafkas Üniversitesi Vet. Fakültesi Derg. 2019, 25, 435-444.

97. Costa-Silva, L.P.; Pinto-Oliveira, J.; Keijok, W.J.; Silva, A.R.; Aguiar, A.R.; Guimarães, M.C.C.; Ferraz, C.M.; Araújo, J.V.; Tobias, F.L.; Braga, F.R. Extracellular biosynthesis of silver nanoparticles using the cell-free filtrate of nematophagous fungus Duddingtonia flagrans. Int. J. Nanomed. 2017, 12, 6373-6381. [CrossRef] [PubMed]

98. Alghuthaymi, M.A.; Almoammar, H.; Rai, M.; Said-Galiev, E.; Abd-Elsalam, K.A. Myconanoparticles: Synthesis and their role in phytopathogens management. Biotechnol. Biotechnol. Equip. 2015, 29, 231-236. [CrossRef] [PubMed]

99. Wang, Y.; Sun, L.; Yi, S.; Huang, Y.; Lenaghan, S.C.; Zhang, M. Naturally occurring nanoparticles from Arthrobotrys oligospora as a potential immunostimulatory and antitumor agent. Adv. Funct. Mater. 2013, 26, 2175-2184. [CrossRef]

100. Khan, I.; Saeed, K.; Khan, I. Nanoparticles: Properties, applications and toxicities. Arab. J. Chem. 2017, 12, 908-931. [CrossRef] 